\title{
Report on the Nudibranchiate Mollusca of Plymouth Sound.
}

\author{
By \\ Walter Garstang, B.A., \\ Jesus College, Oxford; Assistant to the Director M.B.A.
}

THE species included in the present report have all, with one exception, been taken since the opening of the Laboratory in June, 1888. Twenty-four genera and thirty-six species will be found recorded, and these afford a considerable addition to the previously known Nudibranchiate Fauna of the Sound.* Many of the specimens have been obtained north of the breakwater by personally searching under the stones and examining the rock-pools between tide-marks, but the majority have been procured by means of the dredge, the best grounds for this being near the Duke Rock Buoy and around the Mewstone, a fine conical rock which marks the entrance to the Sound on the east.

That the Fauna of the Sound has deteriorated during the last fifteen or twenty years seems undoubted, the cause being the continued increase in the amount of outfall of waste and commercial products from the Three Towns. $\dagger$ Vayssière in his account of the Opisthobranchiate Mollusca of the Gulf of Marseilles reports similar impoverishment of the Fauna due to similar causes. At a part of the coast, he says $(25, \mathrm{p} .7)$, where Haminea cornea, Philine aperta, Aplysia punctata, Doris virescens, Polycera quadrilineata, and numerous Eolids used to be found in abundance, "dans ces deux dernières années il nous a été impossible de rencontrer plusieurs de ces mollusques et ceux qui ont resisté deviennent rares." $\ddagger$ From what I have heard of the zoological condition of other bays along the Devon and Cornish coasts, I have no doubt that, especially among the Nudibranchiata, there are many species to be found in the neighbourhood which have not been taken by us inside the Sound or in the adjacent waters.

Notwithstanding this, some very valuable captures have been made, notably two examples of Idalia aspersa and three specimens of Lomanotus. The latter especially have proved of great interest, and their characters afford a very valuable addition to our knowledge of the genus in British seas. One species of Eolis appears to be new. Moreover, I have throughout tried to make this report not merely a list of species, but as far as possible a contribution to

* Cf. this Journal, No. II, First Series, p. 185.

† See the Director's Report, this Journal, New Series, No. I, p. 5.

I Cf, also some remarks by Thompson of Weymouth (24). 
science. The Zeit-geist is in many quarters making for a re-examination of the very foundations of the theory of Natural Selection, and I trust that the observations here recorded on the subjects of variation, reproduction, rate of growth, colour, and habits of life may be of some service in furnishing facts as regards the life-conditions of this particular group of animals. I further trust that it may not be difficult for others to separate my own theoretical opinions or conclusions from the facts themselves.

During the past year a considerable advance in our knowledge of the value of colour in this group has been made. Darwin* himself seems to have been very doubtful whether the bright tints of Nudibranchs, and especially of the Eolididæ, really served as a protection, except in a few cases; but evidence is accumulating rapidly to prove that in this group colour, whether conspicuous or dull, has a very important value for the individual and species. Giard (6) and Herdman (13) have simultaneously noticed that the colouring of the common Archidoris tuberculata affords a means of rendering it inconspicuous in the localities and positions in which it is usually found. This species feeds usually upon Halichondria panicea, a common spreading shore-sponge, and the colours of the two are very similar. I may point out that this mimetic resemblance is increased by the possession by the Mollusc of a layer of dermal spicules ; an enemy, knowing by inherited instinct, or far more probably by actual experiment and consequent education, the unpalateableness of the sponge, would be doubly deceived as regards the Nudibranch, both by its resemblance to the sponge in appearance and colour, and also by its similar feel. The case of this Archidoris is, however, somewhat complicated; individuals are often found with patches of green or violet colour on the back, and these add to the general inconspicuousness by being the tints of overhanging or surrounding weeds. Indeed, these colours are often seen in the sponge itself. Herdman does not appear to have noticed the mimicry between the Nudibranch and sponge, but he has a very interesting case in which the colour of the former perfectly simulated that of the surrounding rock, Nullipores and Spirorbis tubes.

A case more closely approaching one of true mimicry I came across on the shore at Drake's Island in the early spring of this year. It was that of a small Archidoris Johnstoni fixed on the side of an upright rock between tide-marks, and so exactly resembling a small piece of Halichondria panicea (var. papillaris) that at first I was quite deceived by it. It was situated with the head above and the anus below, the gill-plumes being (as Alder and Hancock state to be usual in the species) half retracted and forming a perforated cone perfectly resembling one of the protruding oscula of the sponge.

* Descent of Man, 2nd ed., pp. 261, 262, 264. 
Several instances of pure "protective resemblance" to a fairly fixed surrounding may be found in Giard, and also one which seems to me to be a case of "mimicry" proper, namely, the resemblance of Eolis papillosa to a contracted Sagartia parasitica, the dorsal papillæ of the former corresponding to the tentacles of the latter. I have placed my remarks upon this most interesting case in my notice of the species (infra). Giard has made a mistake in regarding these cases of protective colouring as instances of a special mimicry existing between the Nudibranchs and the particular species which they affect for prey; but emphasis ought not to be laid upon this point, for (e.g.) Eolis papillosa not only preys upon Sagartia parasitica, but attacks anemones generally.

To what extent the colours of the smaller Eolids are explicable as instances of this mimicry of Actinians, I do not feel prepared to say at present. Wallace* thinks it probable that in some cases at least they are "warning colours as a sign of inedibility."

My own opinion is that the bright colours of the papillæ of Eolids in the majority of cases are serviceable in two ways. Their main purpose is no doubt to warn enemies of the presence of disagreeable qualities (e.g. nematocysts). But from the bright colours being generally confined to the papillæ, which are well known to be detached from the body with the greatest ease, and to be reformed to their full size in two or three days, I think this arrangement must be serviceable in directing the experimental attacks of young and inexperienced enemies to the non-vital papillæ, and away from the vital, inconspicuously coloured parts of the body. The enormous mortality of Nudibranchs $\dagger$ shows what would be the value in the struggle for life of such a means of facilitating the education of enemies, while giving the individuals themselves an additional chance of escape. That butterflies often escape from the attacks of birds owing to the conspicuousness and prominence of their wings, is shown by the many captures of individuals with mutilated wings which have been recorded; but in the case of Eolids such attacks of enemies (fishes chiefly) at the same time give them the needful experience of the unpalatable nature of their intended prey. $\ddagger$ I have, however, experiments in progress for the rerification of these and other ideas as to the value of colour in Nudibranchs and other groups of marine animals.

The ways in which colour probably serves as a protection through-

* Darwinism, London, 1889, p. 266.

$\dagger$ Cf. Darwin, Voyage of Beagle, 2nd edit., p. 245, note.

¥ Since the above was in type Mr. Poulton has drawn my attention to his account of the defensive value of "tussocks" in the larva of Orgyia (Trans. Ent. Soc., 1888, p. 589), which I had quite overlooked. The analogy is remarkably striking. 
out the group are certainly very various, just as they are in Lepidoptera. One case especially is worthy of a moment's notice, viz. that of the tiny Dorid, Efgirus punctilucens. I have only met with one example of this form as yet, but in the conditions in which I met with it (see notice of species, infra) its general colour, form and size were highly protective in the way of rendering it inconspicuous. On a closer view, however, the sparkling blue-green spots which are so characteristic of the species became evident and conspicuous. The idea at once struck me that these spots must be serviceable in some way when the general protective colouring has failed to conceal the animal from its enemy, but of this, from lack of individuals for experiments, I can adduce no proof. Further, the habits of the Nudibranch itself are not at all satisfactorily known; D'Orbigny states it to live upon small species of Ulva, but though I can give no conclusive evidence I am almost sure that the habit which D'Orbigny observed is by no mean normal. Another case which appears to me to be similar is that of Elysia viridis, which is coloured brightgreen and lives among green weeds. On its back, however, are a number of pearly spots in regular rows, very conspicuous upon a close view. I cannot help comparing them with the spots on the back of Airus punctilucens. In Elysia these spots appear to mark the positions of " pouch-like mucous follicles,"* a fact which adds to the interest of the case. I hope shortly to give an account of their structure and function, and of the value to the species of the markings which indicate their presence.

I desire here to express my great indebtedness to my friend and former tutor, Mr. E. B. Poulton, M.A., F.R.S., $\dagger$ for his constant kindness and encouragement; also to $\mathrm{Mr}$. W. Hatchett Jackson, M.A., F.L.S., for the equal value of his friendship and advice; and to Mr. G. C. Bourne, M.A., F.L.S., the Director of the Laboratory, for the time and facilities which he has readily granted me. I must also thank Canon A. M. Norman, M.A., D.C.L., F.L.S., for the help of his experience on several points, and Professor Charles Stewart, M.A., F.L.S., for information about the Fauna of Plymouth Sound in previous years.

In the report I have refrained from discussing anatomical characters, since I have not been able to consult the original papers and monographs of Bergh (with one or two exceptions) and Trinchese. To the same cause I should wish to be attributed whatever imperfections may be found in my classification.

* See Macalister, Introduction to Animal Morphology, part i, 1876, p. 280.

† I need hardly refer to the great suggestive value of Mr. Poulton's numerous papers on the colour, markings, and habits of lepidopterous larvæ and pupæ. 


\section{NUDIBRANCHIATA \\ (= OPISTHOBRANCHIA NON-PAILIATA, Lankester). \\ Sub-order 1-PYGOBRANCHIA, Gray.}

Family-DORIDID A, Leach.

Sub-family-Doridide CRYptobranchiate, Bergh.

1. Archidoris, Bergh.

\section{A. tuberculata, Ouvier.}

Common among the rocks between tide-marks. As many as thirty specimens were obtained on May 31st at Bovisand, north of the pier. Spawn this year most abundant in March and April, but on account of the mildness of the winter and warmth of the spring, marine animals generally have been breeding earlier than usual. On May 29th half-a-dozen specimens were obtained from the shore at Batten, of which one was only three quarters of an inch long, and several others were less than an inch and a half in length. The spawning is prolonged throughout the summer. On August 2nd a young individual was dredged in twenty fathoms off Rame Head, one inch in length. Several large specimens have been met with at various times; the finest, which was five inches in length, was obtained from the mouth of the Yealm on January 21st. It was seen in a fathom of water from the boat's side by W. Roach, our fisherman, and would have been in two feet of water at extreme ebb.

This species usually feeds upon Halichondria panicea, a very common littoral sponge, and* Giard (6) has noticed the general resemblance it bears in form and colour to its prey. It would be more correct to say that it is protectively coloured in relation to its surroundings; see Herdman (13) for a very good case and for his remarks upon it. Professor Stewart tells me that he once obtained on the shore at Cremyll four or five individuals, apparently of this species and at least two inches long, from a mass of Hymeniacidon sanguinea upon which they were feeding, and that, remarkably enough, they were all bright red in colour. Possibly they were examples of Alder and Hancock's species Archidoris flammea, though more than twice the size of their specimens.

\section{A. Johnstoni, $A$. and $H$.}

I have only seen one individual of this species, though Professor Stewart tells me that in former days it was very plentiful. I obtained

* More than fifteen years ago Giard remarked upon the deceptive appearance of this species " au milieu des masses rougeatres des Amarouques qui couvrent le fond" (Arch. Zool. Exp., i, 1872, pp. 553, 558.)

NEW SERIES.-VOL. I, NO. II. 
our specimen from a rock between tide-marks at the east end of Drake's Island in the spring of this year. As I have mentioned in the introduction, this individual had most perfectly the appearance of a young Halichondria panicea, the "blossom-like cup" (A. and H.) formed by the branchiæ simulating the osculum of the Sponge. It was about one inch in length when extended fully, but was very changeable in shape. In appearance it was of a very pale, creamy white colour.

The branchiæ in this individual were twelve in number, but Alder and Hancock state the normal number to be fifteen. I notice that Hancock's figures represent only twelve.*

3. A. coccinea, Forbes.

Between tide-marks on the rocks below the Laboratory, May 14th, one specimen, three eighths of an inch long. One was also obtained in the autumn of last year. Mr. Heape found one on the shore at Ram's Cliff in November, 1886, and again in August, 1887, and also trawled one between the Duke Rock and Drake's Island in November, 1886.

4. A. planata, A. and H.

One specimen, three eighths of an inch long, of a reddish fleshcolour, was obtained with the dredge from near the Duke Rock Buoy May 22nd, 1889. Mr. Heape also obtained one on ground between the Duke and New Grounds' Buoys in November, 1886, between the Duke Buoy and Drake's Island in the same month, and again in Barn Pool January 19th, 1888.

Sub-family.-Doridide phanerobranchiate, Bergh.

Section A. Goniodorine (=Goniodoride, Bergh).

2. ACANTHODORIS, Gray.

5. A. PILOSA, Müller.

One fine specimen, an inch and a half long when not completely expanded, from the estuary of the Yealm, opposite the coastguard station, May 25th, 1889. It would come under Alder's third colourvariety (1), being very black in colour. We have obtained five or six other specimens also, but the record of their capture has been lost. They are quite colourless in spirit, and are not so large as the first-mentioned specimen.

* I have since (Sept. 11th) obtained another specimen from Drake's Island, and in this the branchial plumes are fifteen in number. 


\section{Lamellidoris, Alder and Hancock.}

\section{L. Bilamellata, Linneus.}

Thirty or forty specimens were obtained from the mouth of the Yealm, October 20th, 1888. Occurs also inside the Sound at Batten and Jennycliff. Seven or eight obtained with the dredge from off the Duke Rock, January 23rd this year.

\section{L. sparsa, $A$. and $H$.}

Two specimens of this rare species were obtained with the dredge in fifteen fathoms water off Stoke Point, January 17th, 1889. Each was just a quarter of an inch in length, ovate in form, and nearly equally rounded at both ends. One was of a brownish-pink colour, deepening just behind the tentacles and within the branchial circle, the other was of the same general hue but very pale and slightly purplish in the middle of the back. A character which was marked in each of these specimens, but which Alder and Hancock have not mentioned in the account of their specimen, is that the spiculose tubercles on the back were each surrounded by a ring of blackish pigment, and generally contained a black spot in their centres. Hancock's drawing (Monograph, fig. 3) represents these markings, although there is no mention of them in the text. The tentacles were yellowish white with brown spots or patches; the tubercles on the margins of the tentacular cavities were white with a black spot in the centre of each; but the " obtuse point behind," mentioned and figured in Alder and Hancock's Monograph, was not well marked in either of these individuals. These specimens also did not show the "few distant reddish-brown freckles or spots" on the back which were strongly marked in their example. I believe the branchial plumes were ten in number, but they were very small, not expanded, and hard to make out. The two were kept alive for several days, but were very torpid and remaiued constantly on the bottom or sides of the dish, never being seen to float on the surface of the water.

\section{L. aspera, $A$. and $H$.}

A young individual of this species was dredged between the Mallard and Cobbler Buoys on July 25th of this year. The contents of the dredge were chiefly large quantities of Polyzoa (Bowerbankia imbricata, Bugula flabellata and avicularia), and it was apparently from among these that the Nudibranch emerged after being placed for some time in a dish. It was only one tenth of an inch in length, 
but the dorsal tubercles were so characteristically flattened that there could be no mistake in the identification.

\section{Goniodoris, Forbes.}

\section{G. Nodosa, Montagu.}

Common on rocks between tide-marks in the Sound. In October of last year it was obtained at the following localities-off Ram's Cliff, north of Batten breakwater, at the east end of Drake's Island, one mile west of the Mewstone, and in the estuary of the Yealm. This species, like many other Nudibranchs, comes to the shore in the spring to spawn. Very many large ones were found on the rocks below the Laboratory, near the ladies' bathing place, as early as February this year, and the spawn was abundant in March, April, and May. Young ones were being obtained frequently with the dredge in July.

\section{G. castanea, $A$. and $H$.}

One example, just an inch long, was obtained from the shore at Bovisand, north of the pier, on May 31st of this year. Near it was some spawn which corresponded generally with that described and figured in Alder and Hancock, but the coil was larger and curiously recurved so as to form a sort of figure 8. After finishing the third round in one direction, the animal had begun again on the opposite tack, depositing two coils. It was all in one piece, and probably was deposited by this individual.

\section{IdALia, Leuckart.}

11. I. ASPERSA, $A$. and $H$.

We have obtained two specimens of this rare species. The first was dredged in the estuary of the Yealm on October 20th, 1888. It is rather more than three sixteenths of an inch long in alcohol and corresponds with Forbes's description of I. inæqualis in having the back " circumscribed, elevated, with steep sides," a character which may be exhibited by other individuals of this species aspersa (see Alder and Hancock). It is colourless in spirit, has no median tubercles or filaments on the back, and has the anterior gill-plume and the posterior pair of filaments bifurcated.

The second example was dredged off Penlee Point on June 29th of this year. It was just over half an inch in length and its colour 
was a mottled rosy brown with yellow spots. This colour has largely persisted in alcohol. The two tentacular appendages on each side were as long as, or longer than, the tentacles proper, as Alder and Hancock have represented them, and they were constantly waving about while the animal was alive. The branchiæ were ten in number, but the anterior plume was deeply bifurcated as usual, thus forming eleven points. The posterior plume was not bifid. The lateral filaments were four on each side, the anterior ones very small, the posterior pair very broad at their bases and bifid.

These dorso-lateral rows of filaments are plainly homologous with the ridges found in the genera Polycera, Goniodoris, \&c., and these also with the " epipodial folds" (Lankester, after Huxley) of Archidoris, so that a term to convey this idea would be of service. The " pallial ridges" of Alder and Hancock ought therefore to be termed " epipodial ridges." These structures are of considerable morphological importance and exist to a greater or less extent in every British species (at least) of the family Dorididæ, though often represented by very specialised vestiges (e.g. the branchial appendages of Thecacera); and I believe their homologues are to be seen in Tritonia and Lomanotus, becoming strangely modified in the Eolididæ. Additional ridges are sometimes developed, viz. a median, and a pair of sublateral (cf. Goniodoris, Polycera, Idalia elegans and Leachii).

In view of the variability of the branchiæ and epipodial filaments in this genus I think it must be regarded as certain that Forbes's two specimens of Idalia inæqualis are in reality varieties of $I$. aspersa (cf. Alder and Hancock's Monograph, Appendix, p. v). They were obtained together in thirty-five fathoms in St. Magnus' Bay, Zetland. The habit of associating in couples seems to be very common among Nudibranchs (cf. Giard, p. 502), and I have noticed it in species which are usually found in large groups (e.g. Goniodoris nodosa). If I should prove to be right in regarding the Zetland Idalias as varieties of $I$. aspersa, the Scarborough Tritonias (lineata, A. and H.) as varieties of T. plebeia, and the various British forms of Lomanotus as all of one species, then we should apparently have three instances of selective association between similar varieties in so low a group as the Mollusca.

\section{Ancula, Lovén.}

\section{A. cristata, Alder.}

In March of this year Mr. W. B. Hardy took a fine individual of this species from a tide pool below the ladies' bathing place. It was an inch in length when fully extended. I obtained another specimen between tide-marks near the same place in April. 


\section{Section B.-Polycerina (= Polyceride, Bergh).}

7. Agirus, Lovén.

13. A. PUnCtilucens, D'Orbigny.

Ou March 6th of this year we obtained one of these remarkable little creatures from near the Duke Buoy. Some of the contents of the dredge, consisting chiefly of Hydroids and Polyzoa, had been placed in a dish of sea-water, and after some time I found this Nudibranch to have emerged and made its way to the side of the vessel.

The epipodial ridges are represented in this species by a row of tubercles on each side, somewhat more definitely marked than the rest.

The usual habitat of this species appears to be under stones at lowwater mark (see Alder and Hancock, 1). Balfour obtained it in shallow water in the Firth of Forth (16), and M'Intosh (17) states it to be "not uncommon under stones in rock-pools between tide-marks" at St. Andrews.

For some remarks on the colouration see the Introduction (supra).

\section{Triopa, Johnston.}

14. T. claviger, Müller.

One specimen of this species was obtained on March 29th with the dredge off the Mewstone. The lateral gill-plumes were considerably smaller than the median one. The orange pigment-spots on the back were confined to a median row.

\section{Thecacera, Fleming.}

15. T. pennigera, Montagu.

One example of this rare species was obtained on August 3rd of this year in twenty fathoms off Rame Head. Giard states it to be not uncommon on the coast near the laboratory at Wimereux, and that it is particularly an autumn species, feeding upon Bryozoans of the genus Bugula.

10. Polycera, Ouvier.

16. P. quadrilineata, Müller.

This species is not uncommon. It has been found in Jennycliff 
Bay, in the Cattewater, on the north side of Drake's Island, and on the rocks near the ladies' bathing place, and has been obtained several times with the dredge off the Mewstone and in the estuary of the Yealm. Mr. Heape trawled it several times in Wembury Bay. It is subject to considerable variation, as Alder and Hancock state. In August, 1888, an individual was taken from the north side of Drake's Island which was irregularly spotted with black on a white ground. There were minute yellow tubercles on the body. The velar processes were two, with indication of a third, on the right side, and three on the left. The branchial prominences of the epipodial ridges were normal.

In May of this year a fine specimen from the Cattewater measured just over one inch in length.

On June 5th, from one and three quarter miles south of the Mewstone, was taken an individual of the variety mentioned in the Monograph as possessing no tubercles on the back. There were eight velar filaments, pigmented orange, and there was no pigment elsewhere. The gills and tentacles were normal ; indeed, as yet I have seen no marked variation in the structure of these organs in this species, though such variation occurs, according to Alder and Hancock.

Another specimen of this variety was obtained on June 11th from three miles south of the Mewstone.

Young ones were obtained in tide-pools below the ladies' bathing place in July last year.

17. P. ocellata, $A$. and $H$.

On March 6th was obtained one small specimen of this species from near the Duke Rock Buoy, with the dredge.

Late in June I found three individuals under a stone between tide-marks on the shore under Mount Edgcumbe Park near the "Bridge." On the same small flat stone was some spawn, one and a half times coiled.

\section{Sub-order 2.-CERATONOTA, Lankester.}

Family-TRITONIID五, Johnston.

11. Tritonia, Cuvier.

18. T. Hombergir, Cuvier.

Not uncommon in deep water off the Eddystone, where it is 
brought up in the trawl. A specimen was taken in April, 1888, forty miles north of the Longships lighthouse. Early in May of this year a mass of Molluscan spawn was brought to us by a trawler which I think must have been deposited by one of these fine Nudibranchs. It was in the form of an exceedingly long and narrow ribbon, greatly convoluted, and was-of a salmon-pink colour as nearly as I can remember. I unfortunately did not appreciate its importance at the time and took no notes of it, but I am now almost sure that it must have been the spawn of this Tritonia. On August 25th, 1887, Cunningham dredged a young specimen an inch and a quarter long, in nineteen fathoms' water, one mile south of the Mewstone.

\section{T. PLEBEIA, Johnston.}

This species is taken somewhat frequently. In September of last year I found two specimens in a piece of rock bored by Saxicava, one of them being only half an inch in length. This stone had been brought up with the dredge from south of the Mewstone, and other captures show the species to be fairly common there. One obtained on May 21st showed somewhat peculiar characters. The colour was entirely salmon-pink, deeper on the back from the colour of the liver appearing through the integument. The oral veil was entire, semicircular, and not produced into tentacular prominences, but with a tendency to form four obtuse angles, two on each side. There were five pairs of branchiæ (the anterior pair much the largest) and no small intermediate ones. The edges of the tentacular sheaths were entire, but not so regular as in Hancock's figures in the Monograph. Around each of the branchiæ and around the tentacular sheaths was an area of white pigment, opaque. Length just over half an inch.

This species is also occasionally obtained inside the Sound. One specimen was taken from the Cattewater on November 20th, 1888, and on the next day another was obtained from east of the Mallard Buoy. These, however, had probably been thrown overboard with the rest of the "scruff" from trawlers on their way to Sutton Pool. They were probably at the time fixed to pieces of Alcyonium digitatum upon which they feed, and in relation to which, as Giard has pointed out, their colour and form are evidently serviceable as affording a protective resemblance to their surroundings. On the day of its capture the individual from the Cattewater spawned on a frond of Fucus serratus in a dish; the coil had six perfectly regular turns, attached at short intervals to the weed. The specimen from the Mallard had only four tentacular prominences on the oral veil; 
it was very pale in colour and possessed intermediate branchiæ, differing in these respects from the other individual. The edges of the tentacular sheaths, I noticed, were capable of undulation, though they formed no fixed wavy outline. Several of the characteristics of this individual are thus seen to afford an approach to Alder's species T. lineata, of which he found two specimens at Scarborough. Indeed, I think the distinctness of this species is open to considerable doubt.

\section{Family.-DENDRONOTID $Æ$, Alder and Hancock.}

\section{Dendronotus, Alder and Hancock.}

20. D. arborescens, Müller.

Only one small specimen of this species has been obtained since June, 1888. It was brought up with the dredge from a depth of about twenty-five fathoms south of Penlee Point, in November. It was half an inch in length and had five pairs of branchial appendages, the tufts forming the two last pairs being arranged alternately, not opposite each other. The markings were of a brownpink hue, with yellow tubercles and colouration here and there (cf. Alder and Hancock's variety, pulchella).

A larger specimen, just over seven eighths of an inch in length was dredged in twenty-three fathoms, about three miles south of the breakwater, on February 9th of last year (1888).

Though so rare here, Herdman (12 and 14) reports this species to be abundant at Hilbre Island during the winter months. It is abundant at Wimereux, and has a protective resemblance to the redbrown much-branched weeds of the genus Callithamnion (Giard, 6.)

\section{Lomanotus, Verany.}

21. L. VARIANs, mihi.

On June 11th of this year three Nudibranchs were included in the results of the day's dredging at about three miles south of the Mewstone which I found with pleasure to belong to this rare genus Lomanotus (Eumenis, A. and H.). It was not so easy, however, to assign them to any of the specific divisions which have been founded for the reception of the five hitherto known British examples, and after a careful examination I have come to the conclusion that I must either institute two new species for the specimens which we have dredged or unite the four previously described British species and the three specimens which we have dredged into a single species. 
Reasons drawn from a study of the amount of variation which is exhibited among Nudibranchs generally have led me to take the latter course, although it is not without some diffidence that I do so.

The kistory of the genus in British waters is, so far as I know, as follows: Forty-five years ago Alder dredged a single example near Berry Hear, Torbay, for which he created a new genus (Eumenis) and specifically named Eumenis marmorata. At the time he was not aware that Verany had already published the description of a genus which was identical (as Alder and Hancock subsequently stated in their Monograph) and which had been named Lomanotus by him. In Lamlash Bay, Isle of Arran, another example was dredged by him, for which he created a new species, Lomanotus flavidus. In Weymouth Bay, also, Thompson (24) dredged two specimens, one in December, 1855, the other in December, 1856, which agreed apparently in all the points by which they differed from the two previous examples, and for which Thompson (adopting Alder's view) founded a new species which he named portlandicus. Lastly, Dr. Norman (19) dredging off Berry Head, Torbay (the spot whence Alder obtained his first example), in June, 1875, obtained another fine specimen for which he founded the species Lomanotus Hancocki.

Of the three specimens which we obtained on June 11th two were very closely alike both in size, structure, and colour, and the other was rather larger and much paler in colour and showed certain structural differences. I will describe this one first. In length it was just over five eighths of an inch. It was of a fawn colour, slightly reddish on parts of the back, with numerous small white spots, but without any dark spots or patches. The veil was produced into two tentacular prominences on the right, one on the left. The foot was as usual produced into a curved process at each corner anteriorly, and it was fairly broad as in $L$. marmoratus and flavidus (and probably in $L$. portlandicus and $L$. Hancocki also, since no peculiarity in this respect was noticed). The epipodial ridges formed on each side an almost upright waved expansion undulating into four lobes beset with small papillæ of irregular form, the median one in each lobe being somewhat longer than the rest. This condition is almost exactly the same as that described for L. marmoratus, but in our specimen the four inward undulations of the ridge were considerably more conspicuous than the outward from possessing larger papillæ, these papillæ increasing in size towards the centre of each of the (inwardly-directed) lobes. The waved ridges, indeed, might be said to be broken into four semicircular lobes, whose convexities are directed towards the median dorsal line of the animal. (Compare the definition of the species marmoratus, A. and H., in the 
Monograph, Synopsis, p. 47, " branchiæ forming a nearly continuous waved line of papillæ on each side.") The dorsal tentacles had the same form as in L. marmoratus and were completely retractile within their sheaths. Each sheath was long, stout, and produced at the margin into five or six blunt prominences or tubercles. It is thus seen that this animal differs from Alder and Hancock's marmoratus almost exclusively in the form of the tentacular sheaths and in the colouring; and the doubt arises whether Alder's view of specific characters in this genus can be any longer regarded as correct, since upon it a new species ought to be created for the reception of the iudividual just described.

As was apparently the case with the Weymouth examples, our two other specimens agreed so closely that a single description will serve for both. Length half an inch. Colour much darker than in the preceding specimen, being of a rich, dark, velvety brown, spotted profusely with yellowish white. Veil with four blunt but prominent processes, thicker than in the preceding. Epipodial ridges on each side well marked, thick, fleshy, and foliaceous, undulating four times (four in, four out), the margins beset with bulbous papillæ of which the median ones of the inward undulations were longer than the rest. The outward undulations were as well marked as the inward. Tentacular sheaths spacious and fleshy, each with five projections on the margin. Foot exceedingly narrow and slender, to some extent at least from contraction. On the morning of June 12th each of these individuals had a couple of pieces of spawn upon its back behind the tentacles. Each piece was in the form of an incomplete coil, thickened at the commencement, and in shape much resembling a comma ( $\curvearrowright$ ), the tail being taken, however, rather closer round the head. The two pieces were placed with the "heads " close together and "tails" approaching each other, one of the commas being reversed (mo), and were guarded in this position by the first pair of inward undulations of the epipodial ridges which approached above so as to touch each other in the mid-dorsal line (cf. L. portlandicus). The chief peculiarities common to these two specimens were the dark brown colour, the thick fleshy character of the papillæ (which reminded me of the condition in Egirus punctilucens), and the very slender foot. The fact that these two individuals should present such a close agreement in almost every point (in alcohol one has not quite so much brown pigment as the other) and that the differences between them and the other described British examples of the genus are comparatively considerable, would have been quite sufficient reason for the creation of a new species if I had not paid some amount of attention to the question of variation in the group generally.

In my notice of Tritonia plebeia (supra) I described one or two 
instances of considerable peculiarities of structure in individuals of the species. I showed that the edges of the tentacular sheaths which are usually "entire-edged" may occasionally be somewhat undulate in outline; and one specimen exhibiting this character, in addition to a general paleness of colour and the possession of only four velar tentacles, was seen to bring us very close to Alder and Hancock's species Tritonia lineata, one of the distinguishing characters of which is the possession of " undulating margins" to the tentacular sheaths. Of this "species" only two specimens were (or have been, so far as I am aware) obtained, under stones at Scarborough. Now, the genera Tritonia and Lomanotus are nearly allied, and though they have diverged in certain points of internal structure yet they still retain a great similarity in the structure and form of the dorsum generally and of the epipodial ridges and tentacular sheaths in particular. The undulating ridges of Lomanotus are to be seen in Tritonia Hombergii, although the papillæ of the former have grown into the branchial plumes of the latter, the larger plumes being simply developments of the larger papillæ on the inward undulations in Lomanotus. Therefore having established variations from the usual type of entire-edged tentacular sheaths in a species of Tritonia, I would adduce this as an argument for the probability of variation in the corresponding structures in any given true species of Lomanotus.

Alder founded his species marmoratus because of the entire-edged sheaths and the irregular character of the epipodial papillæ (added to some peculiarities of colour) in his specimen. He judged his specimen flavidus to be specifically distinct because of its possession of tuberculated sheaths and better differentiated papillæ on the epipodial ridges. So also in describing Thomson's specimens from Weymouth, he concluded them to be types of a new species for which he suggested the name fimbriata because of the filamentary character of the processes on the edges of the tentacular sheaths and epipodial expansions. Dr. Norman also founded the species Hancocki partly because of the small size of the dorsal tentacles in his specimen from Torbay, but considerably because the edges of the sheaths were produced into "leaflet-like points" and the papillæ of the lateral expansions were of "flat triangular" form. Norman, however, adds a valuable observation. He says significantly, "The papillæ . .

- are capable of contraction and dilatation, and are constantly changing their apparent dimensions while the animal is in motion." Very probably the "leaflet-like points" of the tentacular sheaths possessed the same contractility of tissue, for the edges of the sheaths and of the epipodial ridges generally possess the same characters.

It is most instructive also to compare the sizes of the different specimens of Lomanotus described. Norman's example was two and 
a quarter inches long and Thomson's specimens were upwards of one and three quarters inches in length. Alder's marmoratus from Torbay was rather more than half an inch, as also was our largest specimen. Our two other specimens were just half an inch, and Alder's flavidus from Lamlash Bay was a quarter of an inch in length. Thus on the theory that they are all of one species we find that the oldest examples (as judged by size) have the greatest differentiation of the margins of the sheaths and of the epipodial ridges, that those nearest together in age are closely alike, and that the youngest individual (flavidus) has the simplest characters.

Altogether the conclusion seems inevitable that all the British specimens so far taken are members of the same species. The main difficulties to my mind are the apparent similarity of Thomson's two specimens (taken at different times in Weymouth Bay) and the close similarity of two of ours. But the difficulties are not sufficient to outweigh the evidence for the conclusion which I have just expressed; variation in Nudibranchs frequently takes place in definite directions (cf. Cavolina Farrani, No. 31, infra), and the Weymouth examples and our two similar individuals may well represent two fixed varieties of the species. It ought to be noted that these two individuals had apparently been copulating, on account of their depositing eggs at the same time. So far as the evidence goes, therefore, we have here a species of Nudibranch producing offspring of very variable external structure, the individuals apparently showing a tendency to unite rather with those of their own variety than with those unlike themselves.

I have to add that I regret to have been unable to consult Verany's account of his species Genei. In all probability it will be found that he has not limited its characters to so extreme a degree as Alder has done with regard to L. marmoratus, flavidus, and portlandicus, and in this case our specimens would probably be referred to L. Genei, Verany. In the meantime I have thought it well to adopt a new name, Lomanotus varians, for the single British species, since to employ any one of Alder's names would lead to confusion.

There is an observation which I omitted to add in its proper place above, viz. that the first described individual was seen by me occasionally to swim vigorously through the water in the dish in which I had placed it, by lashing its body from side to side, much as it is described by Lowe for a Nudibranch from Madeira of the genus Peplidia (vide Alder and Hancock's Monograph, p. 22). The two other individuals were torpid in their movements, and would not expand sufficiently for me to be able to make out the exact dimensions of the foot. 


\section{Family-MELIBEID E, Alder and Hancock.}

14. Doтo, Oken.

22. D. coronata, Gmelin.

This species is common on Plumularia. Early in April a small specimen was dredged one mile south of the Mewstone, and another small one from the same locality on May 27th. In the latter the last branchia was very slender and simple in structure, not tuberculated ; forwards from it there was a regular gradation to those with extensile tubercles. Cf. Herdman and Club, 14, p. 232.

In the collection of preserved specimens there is no undoubted example of $D$. pinnatifida. $\mathrm{Mr}$. Heape has left a record of having found a variety of D. coronata, " or new species," in considerable numbers on Sertularians trawled in thirty-five fathoms, five miles south of the Eddystone.

23. D. rRagilis, Forbes.

Commonly found here on Antennularia ramosa, sometimes on other Hydroids, e.g. Halecium. The habit, so noticeable in this group of Molluses, of individuals of a species going about in couples, is very prevalent in the genus Doto. The two species mentioned above are usually obtained in pairs near the "roots" of Hydroid-stocks.

\section{Family-PROCTONOTIDA, Gray.}

15. Antiopa, Alder and Hancock.

\section{A. cristata, Della Chiage.}

One specimen of this species was dredged west of the Mewstone on June 7 th of this year. It was one and a quarter inches in length. In colour it was very pale, the usual yellowish colour being confined to the laminæ of the dorsal tentacles and the median crest between them. There were opaque white markings along the back in the form of a pair of discontinuous lines, one on each side, from the front of the head to the tentacles and from the tentacles to just behind the heart, where they joined to form a single median discontinuous line running to the tip of the tail.

$$
\text { Family-EOLIDIDA, Gray. }
$$

16. Eolis (= Eolidia in the restricted sense of Gray).

25. E. papillosa, Linneus.

This well-known species is by no means common here now, though 
it is obtained occasionally between tide-marks and in shallow water. Prof. Stewart tells me that it used to be abundant at Cremyll.

Giard has pointed out the great resemblance which an individual of this species bears to a contracted Sagartia troglodytes. It is very probable that we have here a case approaching one of true mimicry, for Actinians are, as a rule, carefully avoided by shore-fish on account of their nematocysts, which, as I have several times tested, are very irritating to the lining membranes of the mouths of fishes. The fish are additionally deceived because of the possession by the Nudibranch of nematocysts at the tips of the papillæ. Some of the shore-fish which frequent rock-pools I have noticed to touch their intended prey, before eating it, with the fleshy margins of the mouth; and the usefulness of the possession of a certain number of irritating thread-cells is at once obvious. Further, the habit, which has been so often noticed in this and other Eolids, of erecting the papillæ when disturbed seems to me to be correlated with this function of the thread cells, for by the bristling up of the papillæ the nematocysts at their tips are placed in the most advantageous position for the assault.

It is very interesting to note that in the two British species of Hermoea, which are inconspicuously coloured with respect to their surroundings, nematocysts appear to be absent. Hermoea bifida lives among red weeds of the genus Griffithsia; the body and papillæ generally are very transparent and of indefinite outline, but the lateral hepatic canals of the body and the branches to the papillæ are highly developed and very conspicuous, having the form and colour of the branches of the weed. The protective resemblance is here very perfect, though there still seems to be another resource for the animal when discovered, viz. the ejection, when touched, of a fetid, colourless fluid (see Alder and Hancock, 2).

Hermoe dendritica is coloured bright green, with dendritic markings, and lives upon the green weed Codium tomentosum.

For description of another possible species of this genus see No. 32 .

\section{Facelina, Alder and Hancock.}

\section{F. coronata, Forbes.}

Late in March of this year a specimen of this species, one and a quarter inches in length, was dredged off the Mewstone. On May 11th six magnificent specimens were dredged off the same ground, with a mass of Syncoryne. Some spawn was brought up as well, and a young individual was only three eighths of an inch long. 
For the carnivorous habits of this beautiful Nudibranch see Alder and Hancock (2) and Gosse (7).

\section{Flabellina, Cuvier.}

27. F. punctata, $A$. and $H$.

On May 11th one specimen was dredged, just over an inch in length, from one mile south of the Mewstone. The rose colour of the head and back was much deeper in this than in Alder's individual from Torbay. The dorsal tentacles were coloured dark brown along the middle third of their length, especially at the sides on the lamellæ; the upper third of the tentacles was pale in colour.

\section{Coryphella, Gray.}

28. C. Rufibranchialis, Johnston.

Examples of this species were obtained by Mr. Heape in twenty to twenty-five fathoms off Whitsand Bay and ten miles south-east of Plymouth, in May, 1887. We dredged two splendid specimens along with a number of other Eolids on May 11th this year, one mile south of the Mewstone. Three more were dredged on June 11th in twenty fathoms, three miles south of the same rock.

\section{C. Landsburgit, $A$. and $H$.}

I took a small example of this rare and beautiful species from an Antennularia-stock dredged near the Duke Rock, in January last. It was only three sixteenths of an inch long. The colour was a beautiful, very transparent, pale violet, deepest on the lower part of the tentacles. The hepatic cæca of the dorsal papillæ were orange red in colour, with numbers of small, dark brown spots. The papillæ were arranged in four or five clusters, very ill-defined after the first set. They were very long in comparison with the size of the body, the largest being as long as the oral tentacles. They were not so stout as in Alder and Hancock's individual, and were capable of considerable flexion and extension. The opaque white ring near the tip of the papillæ was well marked. The dorsal tentacles were set well apart at the base.

This individual was kept alive for some weeks; the heart could easily be seen beating between the first and second clusters of papillæ.

Haddon (11) and Herdman (12) report the capture of individuals, probably of this species, of much larger size. 


\section{Cavolina, Cuvier.}

30. C. olivacea, $A$. and $H$.

One specimen, dredged on May 11th, one mile south of the Mewstone. It was three eighths of an inch in length. The two pairs of lateral streaks of rose colour on the head were very well marked.

\section{C. Farrani, A. and $H$.}

Two examples of this species were obtained at different times during October, 1888, from the Cattewater. The dorsal tentacles were short and rather thick. The oral tentacles were thicker and longer than the dorsal, entirely orange in colour, and constricted at the bases. One of them deposited some spawn, attached by the edge and coiled two and a half times.

On November 1st a number of Eolids were found on the blades of some Laminaria saccharina from the Cattewater (under Queen Anne's Battery), on which extensive stocks of Obelia geniculata were growing. I described and classified them at the time as follows:

"A. Cavolina Farrani.-White in colour, with orange-tipped branchiæ. Seven or eight.

"B. Cavolina, sp.-Length half an inch or more. Dorsal tentacles rather longer than the oral but more slender. Body transparent, whitish, marked on the back with large patches of orange red. Branchial papillæ inflated or elliptical; in six, seven, or eight rows, three papillæ on each side; of olive-green colour, orange at tips. Dorsal and oral tentacles coloured like the branchiæ. Large oval patch of yellow pigment behind the dorsal tentacles. Back of head olive brown, merging into orange red below (i.e. in front of the bases of) the dorsal tentacles.

"In the larger specimens the colours of the branchiæ and back were much intensified, the branchix being of a deep purplish black, and the back being mottled with deep orange red. The upper large branchiæ had whitish, not orange, tips. The oral tentacles were almost entirely orange in colour; the dorsal tentacles were long and cylindrical. Five or six specimens."

The examples of Eolis Farrani which Mr. Murray obtained on the coast of Elgin were mainly of a purplish or umber tint, and the colour of the tips of the branchial papillæ was "generally whitish, with only a slight tinge of orange" (see Alder and Hancock's Monograph, Appendix, pp. xi, xii). M'Intosh also has obtained "fine purple varieties" at St. Andrews, and his figure shows the presence of deep orange-red pigment (17, plate ii, fig. 13), therefore I think NEW SERIES.-VOL. I, NO. II. 
there can be little doubt that our specimens were varieties of the same species, Cavolina Farrani. Compare also M'Intosh's Eolis Andreapolis (18), probably a variety of C. Farrani, not a distinct species.

"C. Cavolina, sp.-Same generally as B, but the tips of the branchiæ are of an opaque white, instead of orange, and very conspicuous. The patches of colour on the back are crimson rather than orange, and the integument has the appearance of velvet. One specimen."

Probably also a variety of $C$. Farrani.

"D. Cavolina, sp.-Half an inch in length. Body slender. Branchiæ numerous. Entirely white in colour. Two specimens."

No doubt another variety of $O$. Farrani.

"E. Cavolina, sp.-Half an inch in length. Body slender. Entirely orange in colour. Tentacles equal in size. Branchiæ inflated, in six or seven rows of three papillæ on each side. Central gland much sacculated. Papillæ with specks of opaque orange; no specks on the tentacles. Radula as figured and described by Alder and Hancock for Eolis Farrani. One specimen."

Certainly a variety of the same species. Compare also M'Intosh's Eolis Robertianæ (18).

All these Eolids were feeding upon Obelia geniculata, and were obtained from the same blades of Laminaria. As they all agreed so far as structure is concerned (except as to slight variations in the length of the tentacles), there can be hardly any doubt that they are members of the same species Cavolina Farrani, A. and H. ; and in trying to estimate the value of colour in the Eolididæ it is certainly very puzzling to find almost equal numbers of two very different colour-varieties (A and B) of a species living under exactly the same conditions. I am not quite sure yet of the reason for this dimorphism.

With the above-described examples of Cavolina Farrani taken from the Laminaria on November 1st there was another Eolid which for convenience' sake I will describe here, although its structure does not admit of its being placed in the same genus.

\section{Eolis? sp.}

Body half an inch in length. Foot produced at the corners anteriorly. Dorsal tentacles wrinkled with regular annuli, not laminated; set considerably apart at their bases. Branchial papillæ in fourteen or fifteen rows, four papillæ on each side ; papillæ slender in form. Oral tentacles longer than the dorsal. Colour of body transparent white; glands of branchiæ yellowish. Opaque white spots at tips of branchiæ in the form not of complete rings but of semilunar or crescentic patches on their anterior faces. Very cha- 
racteristic was a beautiful opalescent pale blue colouring on the back of the head between the oral and dorsal tentacles, on the inner faces of the oral tentacles, and on the anterior faces of the larger branchial papillæ. On the posterior faces of the branchiæ this colour became more pink than blue. It was also made out slightly along the back and markedly on the back of the foot or " tail." Here at the very extremity it merged into a patch of the ordinary opaque white spots. The individual lived very well in a dish for several days, but an accident very unfortunately prevented me from examining the radula.

I know of no species to which this remarkable little Eolid can be referred; if it should prove to be new I would suggest for the species the name Eolis Huxleyi, in honour of the President of our Association.

\section{Galvina, Alder and Hancock.}

33. G. cingulata, A. and $H$.

We have obtained this species on two occasions. On June 11th one specimen was dredged in twenty fathoms three miles south of the Mewstone. It was not quite three eighths of an inch long and possessed nine rows of branchiæ. The lateral lines of olive-brown between the bases of the papillæ were broad and well marked. The tentacles were pale in colour, and there was no patch of pigment behind. The animal was very active and restless.

On August 7th another specimen was obtained from the estuary of the Yealm. When fully extended it was very slender and measured just over three eighths of an inch, but it possessed only five rows of papillæ. The olive-brown pigment was diffuse at the sides and did not form distinctly marked lateral lines. The ring of bright red colour on each of the tentacles shown in Hancock's figures was represented by a band of reddish brown in this individual. The papillæ often assumed a contracted and tuberculated state, such as is persistent in the genus Doto.

\section{Tergipes, Cuvier.}

34. T. DEsPeCta, Johnston.

Large numbers of these minute Eolids were found crawling about on the hydrosomes of extensive colonies of Obelia geniculata growing on Laminaria saccharina from off the Mewstone on March 28th of this year. The majority were transparent and quite colourless, having simply an opaque white mass at the tip of each papilla. The dorsal tentacles were constantly long and slender, while the oral tentacles in some individuals could barely be made out at all. The papillæ were slender and not very club-shaped; they were, as usual, 
pointed at the tips. There was considerable variability in the arrangement of the papillæ, mainly due, however, to the animals being in different stages of growth. In the majority of individuals there was a pair in front, set opposite each other, and then two or three other papillæ behind them, arranged alternately, of which the first-formed one seems always to be on the left side. The heart was situated behind the first pair. In the largest individual, which was only one eighth of an inch in length, there were five pairs of papillæ, the second and fourth being the largest, with a single papilla on the left side behind the last pair. The heart was situated between the second and third pairs. The first pair was double, having two papillæ on each side, the outer ones being very small. In this large individual there was some faint brownish-yellow or slightly olivaceous pigment scattered over the body and on both pairs of tentacles. The "glands" of the papillæ were somewhat sacculate and of a faint yellowish-brown colour. The usual opaque white at the tips was yellowish at the extremity and faintly bluish in an ill-defined ring just below.

In one individual examined, which possessed remarkably long and slender dorsal tentacles, the left tentacle showed an abnormality in the form of a linear and slender outgrowth close to its base, directed backwards and outwards, and larger than either of the oral tentacles. M'Intosh figures a somewhat similar abnormality in the same tentacle of a Doto coronata (17, plate ii, fig. 14).

The spawn of this variety of Tergipes despecta was abundant on the stems of the Hydroid. The masses were not so reniform as they are represented by Alder and Hancock; they are more or less spherical in shape, slightly compressed from side to side and flat or very slightly concave along one edge (the hilum), from the centre of which proceeded a short gelatinous stalk for attachment. This stalk was constantly present, although I do not find it described for either Tergipes despecta or exigua. The spawn-masses varied in size, some containing only a quarter the number of ova found in the majority. The size of the spawn-masses was never so large as indicated in Alder and Hancock for T. despecta, and their shape was never so oblong and reniform as figured for T. exigua. The eggs were contained each in a separate capsule, and the larvæ possessed very long cilia on the edges of the velar lobes.

These little Eolids appeared to me to feed not upon the Hydroid itself but upon the minute Algæ which accumulate on its stems and branches.

Giard thinks the egg-masses of this genus to be of such form and colour, and to be so arranged upon the stems, as to imitate the gonosomes of the Hydroids upon which they are found. 


\section{Sub-order 3.-HAPLOMORPHA, Lankester. Family-ELYSIADA, Alder and Hancock.} 23. Elysia, Risso.

35. E. viridis, Montagu.

This interesting species was dredged in the estuary of the Yealm in some numbers on October 20th, 1888, and was again obtained there early in August of this year. This animal lives among green weeds (Codium tomentosum, Zostera marina) and its general bright green colour is certainly protective. The value of the "lustrous specks" of blue or rose colour I have not been able to prove as yet. Whatever their meaning, they will probably be found to have the same value as the spots of sparkling blue on the back of Aigirus punctilucens. See some remarks in the Introduction.

$$
\text { Family-LIMAPONTIAD } \text { Æ, Gray. }
$$

24. Limapontia, Johnston.

36. L. NIGRA, Johnston.

Found by Mr. Heape on the Reny Rocks, February 6th, 1888.

\section{LIST OF SPECIAL WORKS AND PAPERS CONSULTED.}

1. Alder, Joshua.-A Catalogue of the Mollusca of Northumberland and Durham. Trans. Tyneside Naturalists' Field Club, vol. i, 1850.

2. ALDER and HANCOCK.-Monograph of the British Nudibranchiate Mollusca. Ray Society, 1845.

3. Bergh, Rudolph.-Report on the Nudibranchiata. Challenger Reports, Zoology, X, pt. xxvi.

4. Fuming, John.-A History of British Animals. Edinburgh, 1828.

5. Forbes and HANLezy.-A History of the British Mollusca. London, 1853.

6. GIARD, AlfRED.-Le Laboratoire de Wimereux en 1888: Recherches Fauniques. Bull. Sci. de la France et de la Belgique, iiie série, ix-xii, 1888, pp. 493, 499-503.

7. Gosse, P. H. -A Year at the Shore. London, 1865, pp. 38-45. (Archidoris tuberculata, Triopa clavigera, Facelina coronata.)

8. Grat, J. E.-Guide to the Systematic Distribution of Mollusca in the British Museum, part i. London, 1857.

9. HADDon, A. C.-Preliminary Report on the Fauna of Dublin Bay. Proc. Roy. Irish Acad., 2nd ser., vol. iv, No. 5, 1886.

10. Haddon, A. C.-First Report on the Marine Fauna of the South-West of Ireland. Proc. Roy. Irish Acad., 2nd ser., vol. iv, No. 5, 1886.

11. HADDON and GRERN.-Second Report on the Marine Fauna of the South-West of Ireland. Proc. Roy. Irish Acad., 3rd ser., vol, i, No. 1, 1888, p. 39.

12. Herdman, W. A.-Report on the Nudibranchiata of the L.M.B.C. District. First Report upon the Fauna of Liverpool Bay and the Neighbouring Seas. London, 1886. 
13. Herdman, W. A.-Inaugural Address on some Recent Contributions to the Theory of Evolution. Proc. Liverpool Biological Society, vol. iii, 1889, pp. 13-15. (Protective colouration in Archidoris tuberculata.)

14. Herdman and ClubB.-Second Report on the Nudibranchiata of the L.M.B.C. District. Proc. Liv. Biol. Soc., vol. iii, 1889.

15. Lankester, E. RaY.-Mollusca. Encyclopædia Britannica, 9th edit., vol. xvi.

16. Leshir and Herdman.-The Invertebrate Fauna of the Firth of Forth. Edinburgh, 1881.

17. M'Intosn, W. C.-The Marine Invertebrates and Fishes of St. Andrews. Edinburgh, 1875 .

18. M'Intosh, W. C.-On the Nudibranchiate Mollusca of St. Andrews, Proc. Roy. Soc., Edinburgh, 1864-65.

19. Norman, A. M.-On two New British Nudibranchiate Mollusca: Eolis sanguinea, n. sp., and Lomanotus Hancocki, n. sp. Ann. and Mag. of Nat. Hist., Dec., 1877.

20. Pennant, Thomas.-British Zoology, vol. iv, 1777.

21. Poulton, E. B.-Notes upon the Markings, \&c., of Lepidopterous Larva and Pupa. Trans. Entom. Soc., 1883-1887.

22. Poulton, E. B.-The Experimental Proof of the Protective Value of Colour and Markings in Insects in reference to their Vertebrate Enemies. Proc. Zool. Soc., March, 1887.

23. Rorssy, Felix DE.-Histoire Naturelle des Mollusques (Suite à Buffon), Tome v. Paris, An. xiii.

24. Thompson, W.-On a Species of Eolis, and also a Species of Lomanotus new to Science; with the Description of a Specimen of Eolis cerulea of Montagu. Ann. and Mag. of Nat. Hist., vol. v, 3rd series, 1860, pp. 48-51. (The descriptions are by Alder and Hancock, who also made drawings of all the specimens, apparently not published.)

25. VAYssière, M. A.-Recherches Zoologiques et Anatomiques sur les Mollusques Opistobranches du Golfe de Marseille. I ${ }^{e}$ Partie: Tectibranches. Ann. Mus. Hist. Nat. Marseille: Zoologie II, 1885, Mém. No. 3. 